\title{
The millipede family Striariidae Bollman, 1893. IV. Amplaria oedipus, n. sp., with a secondary sexual modification of males unique among millipedes (Diplopoda, Chordeumatida, Striarioidea)
}

\author{
WILLIAM A. SHEAR ${ }^{1 *}$, PHILIP NOSLER ${ }^{2} \&$ PAUL E. MAREK ${ }^{3}$ \\ ${ }^{I}$ Professor Emeritus, Department of Biology, Hampden-Sydney College, Hampden-Sydney VA 23943 USA, current address: 1950 Price \\ Drive, Farmville VA 23901 USA. \\ 28921 Wooded Hills Court, Damascus OR 97089. झ" philnosler@gmail.com \\ ${ }^{3}$ Department of Entomology, Virginia Tech, Blacksburg VA 24061 USA. \\ ="pmarek@vt.edu; ○ https://orcid.org/0000-0002-7048-2514 \\ "Corresponding author. ”"wshear@hsc.edu; 이ttps://orcid.org/0000-0002-5887-7003
}

\begin{abstract}
A new species, Amplaria oedipus, is described from Oregon, USA. Males of the new species have greatly inflated pyriform tarsi on the 5th and 6th legpairs, which is a secondary sexual modification previously not known from any other millipede.
\end{abstract}

Key words: new species, Oregon

\section{Introduction}

The millipede family Striariidae Bollman, 1893 is endemic to North America, occurring both in the southern Appalachian Mountains of the eastern United States, and from southern California north to southern British Columbia (unpublished records), including the U.S. states of California, Oregon, Washington and Idaho. Members of the family show a unique morphology, with a hood-like collum, crested metazonites and a trilobed telson (pygidium in most previously published accounts of millipedes; we write telson to use a more universal terminology in arthropods). Amplaria Chamberlin, 1941 is the most frequently encountered genus in the western distribution of the family, found in all states where striariids are present. Previous papers in this series (Shear \& Krejca 2007, Shear et al. 2017, Shear 2020, 2021a, 2021b) have resulted in an improved understanding of diversity in this genus, which presently consists of 18 species (including the one described here; see below for a key and list), two of them highly adapted troglobionts.

Amplaria species males have an extensive suite of secondary sexual modifications, which occur in varying combinations in the 18 species, including labral spurs, acute projections of the mandibular stipes, specialized setae of the first legpair, various morphologies of the basal podomeres of the second legpair, long flask-like extensions of the third coxae (which often have reduced telopodites), and enlargement and flattening of legpairs 4-7, as well as gonopods developed from the eighth legpair and strongly reduced ninth legs, consisting only of a coxa (or coxosternum) and single telopodite article. The new species described below shows an additional modification previously not seen elsewhere in the order Diplopoda: the tarsi of the fifth and sixth legpairs are enormously swollen and pyriform (Figs 3, 6, 7). This is so distinctive that a new genus was briefly contemplated, but studies of other characters, especially the gonopods, convinced us that the species was best accommodated in Amplaria. 


\section{Methods}

Specimens were field-preserved in $90 \%$ isopropanol and later transferred to $70 \%$ ethanol. Morphological studies were done using an Olympus SZH stereomicroscope and an Olympus BX50 compound microscope equipped with Nomarski optics. Gonopods were temporarily mounted on microscope slides in glycerine for study up to $400 \mathrm{X}$ magnification and drawings were made from these slides using a drawing tube on the BX50. For scanning electron microscopy (SEM), specimens were mounted on $12.7 \mathrm{~mm}$ diameter aluminum stubs, using double-sided carbon discs. These were sputter coated with a $40 \mathrm{~nm}$ thick layer of platinum and palladium, using a Leica EM ACE600 high vacuum sputter coater. SEM micrographs were taken with a FEI Quanta 600 FEG environmental scanning electron microscope. Photographs were edited and refined using GIMP, and plates were composed in InkScape.

Type specimens are deposited in the collection of the California Academy of Sciences, San Francisco, California, USA, along with the SEM stub, WS36-15, to be deposited later.

\section{Abbreviations used in the figures}

\begin{tabular}{|c|c|}
\hline aac & anterior angiocoxite \\
\hline c (numeral) & numbered metazonite crests \\
\hline ср & coxal process \\
\hline ef & coxal flask of legpair 3 \\
\hline $\mathbf{c x}$ & coxa \\
\hline cx (numeral) & coxa of numbered legpair \\
\hline fc & flagellocoxite \\
\hline lab & labrum \\
\hline lcc & lateral lobe of colpocoxite \\
\hline lh & labral hook \\
\hline ms & mandibular stipes \\
\hline numerals & ring numbers \\
\hline pac & posterior angiocoxite \\
\hline pce & posterior lobe of colpocoxite \\
\hline pf (numeral) & prefemur of numbered legpair \\
\hline $\mathbf{s}$ & sternum of gonopods \\
\hline s (numeral) & sternum of numbered legpair \\
\hline t (numeral) & tarsus of numbered legpair \\
\hline tel & telson \\
\hline $\operatorname{tr} 2$ & trochanter of legpair 2 \\
\hline $\operatorname{trp}$ & trochanter process \\
\hline vd & openings of vasa deferentia \\
\hline
\end{tabular}

\section{Taxonomy}

Family Striariidae Bollman, 1893

\section{Subfamily Striariinae Bollman, 1893}

\section{Genus Amplaria Chamberlin, 1941}

For synonymy and a detailed discussion of the genus, see Shear (2020, 2021a). 


\section{Amplaria oedipus Shear, Nosler \& Marek, new species}

Figs 1-13.

Types: Male holotype and female paratype from Cape Mountain, near Florence, $44.0947^{\circ},-124.0756^{\circ}$, Lane Co., Oregon, collected 18 September 2021 by Phil Nosler; male paratype from same locality but $44.0954^{\circ},-124.9766$, collected 25 September 2019 by Phil Nosler.

Parts of male paratype on SEM stub WS36-15. All specimens deposited in California Academy of Sciences.

Diagnosis: This species cannot be confused with any other, due to the unique modification of the tarsi of male legpairs 5 and 6, which are enormously swollen and pyriform (Figs 3, 6, 7).

Etymology: The species epithet is a noun in apposition, a Greek proper name. Oedipus is a well-known figure from Greek mythology and the subject of two tragedies by Sophocles. The name Oedipus means "swollen foot" and is therefore appropriate for this unusual species.

Description: Male holotype. Body with 30 rings (including telson). Length, about $12 \mathrm{~mm}$, width $1.2 \mathrm{~mm}$ at midbody. Ocularium with 12 or 13 ommatidia. Labrum (lab, Fig. 1) with acute spines (lh, Fig. 1) at distal corners. Mandibular stipes (ms, Fig. 1) lacking projections, rimmed with rounded teeth. Collum white, with 10 low crests, sixth crest on each side vaguely noticeable. Metazonite ornamentation (Fig. 2) typical of the family, with 12 crests, prominent and equal, wider spacing between crests 2 and 3, and 4 and 5 on each side. Rings with two longitudinal bands of purplish brown pigment; crests 2 and 3 of each side within these pigmented bands thereby making crests appear with darker pigment. Segmental setae short, distally with a brush of small spinules. Telson (tel, Fig. 2) slightly elongated, 3-lobed. Cerotegument lacking in all specimens so far examined.

Legpair 1 white, reduced, smallest of all legs (Fig. 1), needle-like setae lacking, but femora with flattened specialized setae. Tarsi of legpair 1 (t1, Fig. 1) with comb setae. Remaining legpairs with purplish brown pigment. Legpair 2 (Figs 1, 4) with vasa deferentia (vd, Fig. 4) opening from unmodified coxae (cx2, Fig. 4); with rounded, bulging trochanters (tr2, Fig. 4) with short processes bearing modified setae (trp, Fig. 4); and with enlarged, flattened prefemora (pf2, Fig. 4). Legpair 3 (Figs 3, 5) with short, curved coxal flasks (cf, Fig. 5) distally with curled setae; and with telopodites not enlarged but femora flattened, lower surface with evenly scattered small tubercles (Fig. 3). Postcoxal bars of ring 3 long, distally expanded, meeting or crossing in midline. Legpairs 4-7 (Fig. 3) much enlarged, with flattened femora; legpairs 5 and 6 with greatly swollen pyriform tarsi (t5, t6, Figs 3, 6, 7) about 0.5 $\mathrm{mm}$ long and $0.4 \mathrm{~mm}$ in diameter, tapering proximally to articulation with tibiae and tapering distally at tarsungulum (Fig. 7), but nearly spherical in distal view (Fig. 6). Legpair 7 without coxal lobes covering bases of gonopods (Fig. $3)$.

Gonopods (Figs 8-10, 12,13) with structure typical of Amplaria. Anterior angiocoxites (aac, Figs 8, 10, 12, 13) slightly curved, distally hook-like, with small, bifurcate posterior distal process (Fig. 9). Posterior angiocoxites (pac, Figs 8-10, 12,13) about half the length of the anterior angiocoxites, long, projecting anterior branch sheaths at least 3 flagellocoxites (fc, Figs 8, 13). Posterior lobes of colpocoxites (pcc, Figs 8, 13) with finely spiculate surface. Lateral lobes of colpocoxite (lcc) large. Ninth legpair (Fig. 11) with mesally hooked coxal process (cp, Fig. 11), telopodite setose, flattened, mesally with recess receiving coxal process. Telopodites fitting into shallow depressions in ventrolateral margins of seventh diplotergite. Tenth leg coxae with coxal glands.

Female paratype. Similar to male but with smaller collum, less projecting pygidium and lacking the greatly inflated tarsi on the 5th and 6th legpairs, and other male secondary sexual modifications.

Distribution: Known only from Cape Mountain, Lane Co., Oregon.

Notes: Collections were made by hand in early fall to late spring. Most searches were made along the main trail to the peak of Cape Mountain (accessed from the parking lot at Dry Lake Horse Camp). All specimens were collected from the vicinity of the peak. Litter and soil were examined, as well as the undersides of logs, rocks, and bark. Specimens were fixed in 90\% isopropanol and preserved in 70-80\% ethanol.

The habitat at this location is a Sitka Spruce (Picea sitchensis (Bong.) Carrière) forest. In Oregon, this is a unique ecosystem found only in very close proximity to the Pacific coast, where the climate is mild and wet (Franklin and Dyrness 1988); Cape Mountain lies approximately $5 \mathrm{~km}$ from the coast. Sitka Spruce is the dominant conifer in this habitat, and is supplemented by Western Red Cedar (Thuja plicata Donn ex D. Don) and Red Alder (Alnus rubra Bong.) in disturbed areas. The undergrowth consists of dense Salal (Gaultheria shallon Pursh), Western Sword-fern (Polystichum munitum (Kaulf.) C. Presl), Salmonberry (Rubus spectabilis Pursh), Red Elderberry (Sambucus racemosa Linnaeus), Evergreen Huckleberry (Vaccinium ovatum Pursh), and Red Huckleberry (Vaccinium parvifolium $\mathrm{Sm}$. in Rees). 

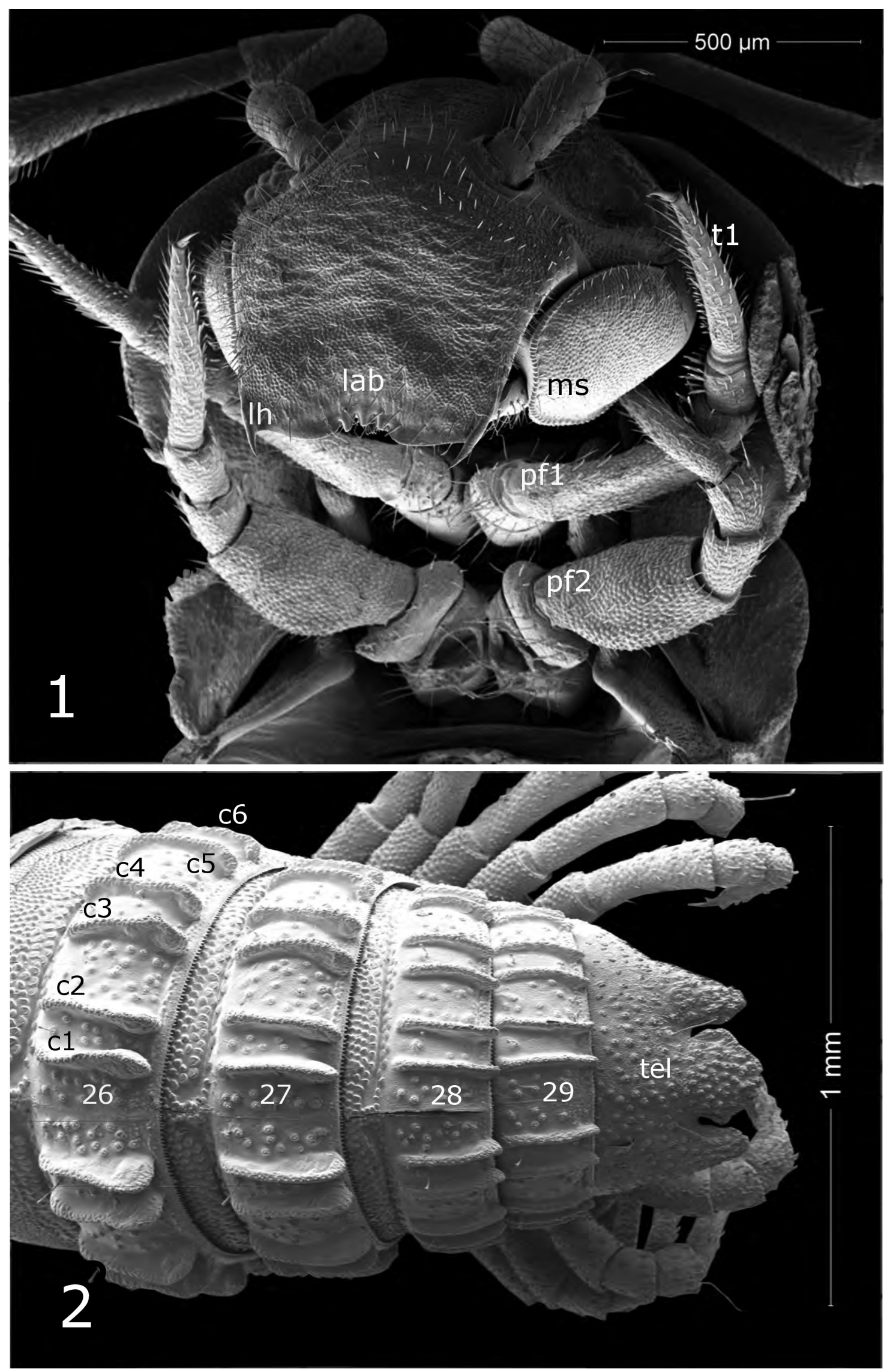

FIGURES 1 and 2. Amplaria oedipus n. sp., male paratype. Fig. 1. Head and anterior legs, ventral view; lab, labrum; lh, labral hook; ms, mandibular stipes; pf1, prefemur of first leg; pf2, prefemur of second leg; t1, tarsus of first leg. Fig. 2. Rings 26-29 and telson; numerals, ring numbers; c (numerals), crest numbers of right side of ring 26; tel, telson. 

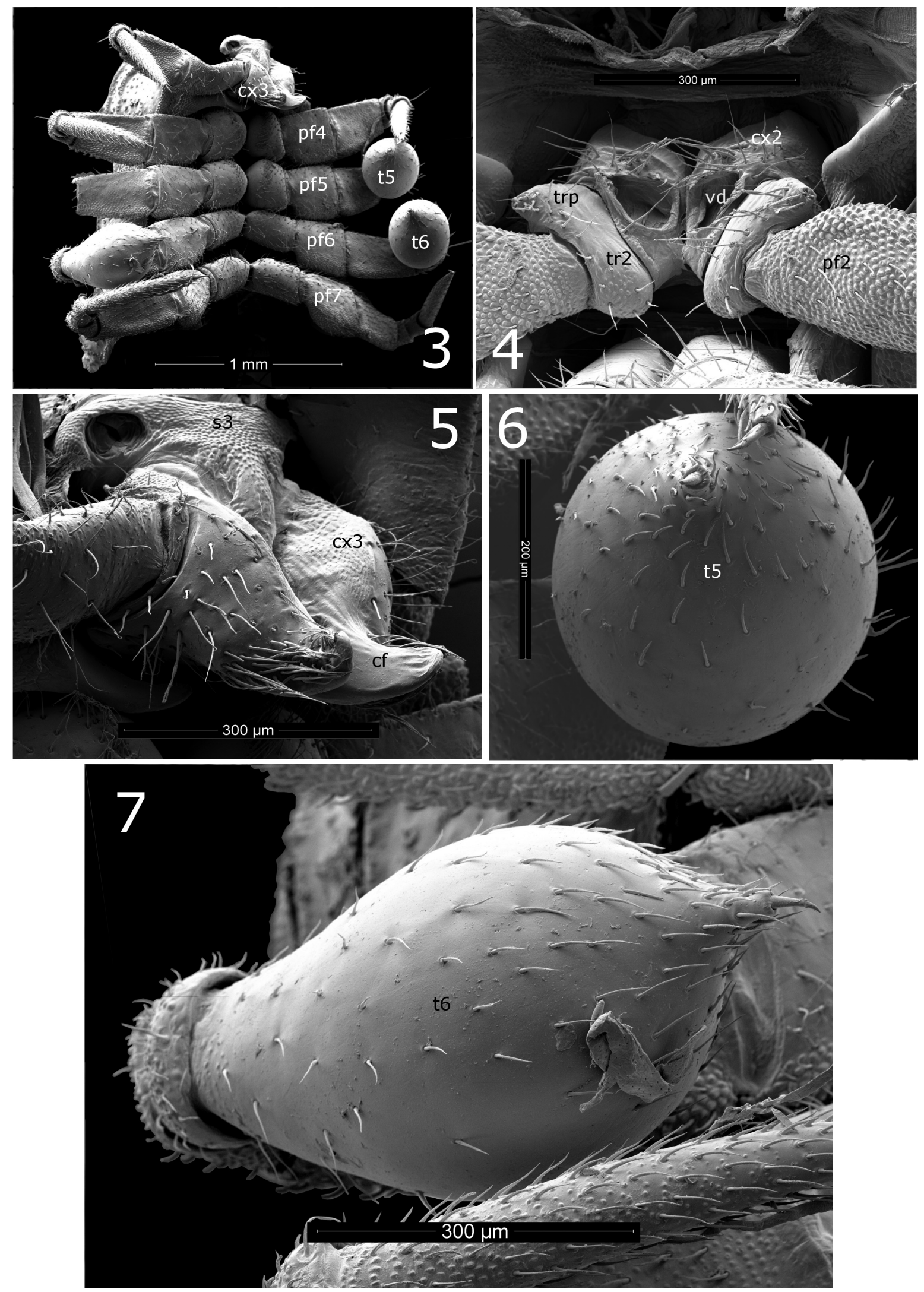

FIGURES 3-7. Amplaria oedipus, n. sp., male paratype. Fig. 3. Legpairs 3-7, ventral view; cx3, third leg coxa; pf(numeral), prefemora of legs 4-7; t(numeral), greatly inflated tarsi of legs 5, 6. Fig. 4. Bases of legpair 2, ventral view; cx2, coxa of second leg; pf2, prefemur of leg 2; tr2, trochanter of second leg; trp, trochanteral process; vd, opening of vas deferens. Fig. 5. Bases of legpair 3; cf, coxal flask of third leg; cx3, coxa of third leg; s3, sternum of third leg. Fig. 6. Greatly inflated tarsus of left fifth leg, distal view; t5, tarsus of fifth leg. Fig. 7. Greatly inflated tarsus of right sixth leg, lateral view; t6, tarsus of sixth leg. 
Amplaria oedipus was always found at or near the litter surface. The male paratype was found underneath a small, broken branch which also supported platydesmid and rhiscosomid millipedes. The male holotype and female paratype were found in leaf litter. Amplaria oedipus was found in places rich with other chordeumatidan families, including Caseyidae, Tingupidae, and Conotylidae.
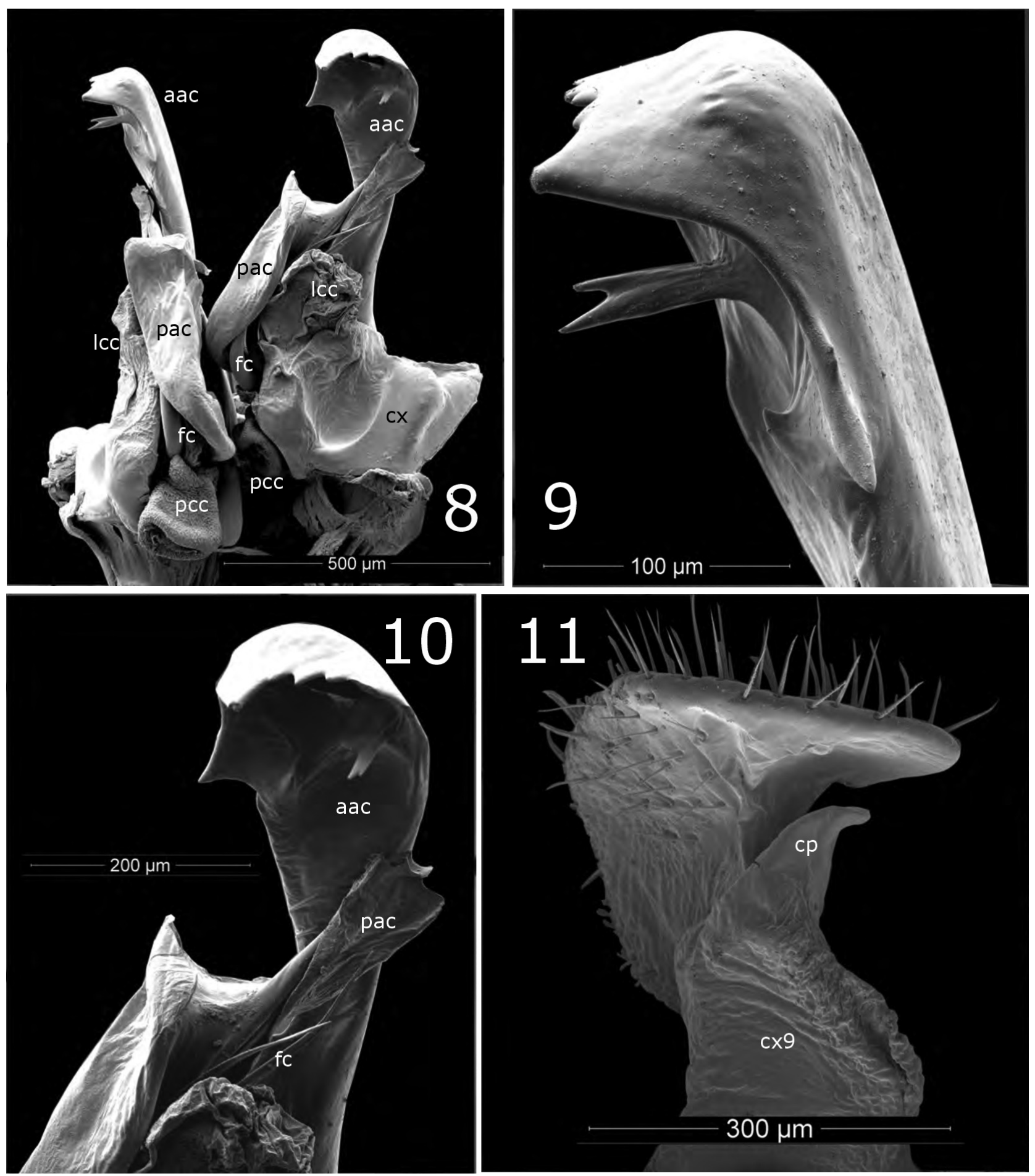

FIGURES 8-11. Amplaria oedipus, n. sp., male paratype. Fig. 8. Gonopods, posterior view; aac, anterior angiocoxite; cx, gonopod coxa; fc, flagellocoxite; lcc, lateral lobe of colpocoxite; pac, posterior angiocoxite; pcc, posterior lobe of colpocoxite. The lateral lobe of the colpocoxite has collapsed due to drying for SEM. Fig. 9. Tip of left anterior angiocoxite, mesal view. Fig. 10. Tips of right anterior and posterior angiocoxites, posterior view; aac, anterior angiocoxite; fc, flagellocoxite; pac, posterior angiocoxite. Fig. 11. Left leg 9, anterior view; cp, coxal process; cx9, coxa of leg 9. 


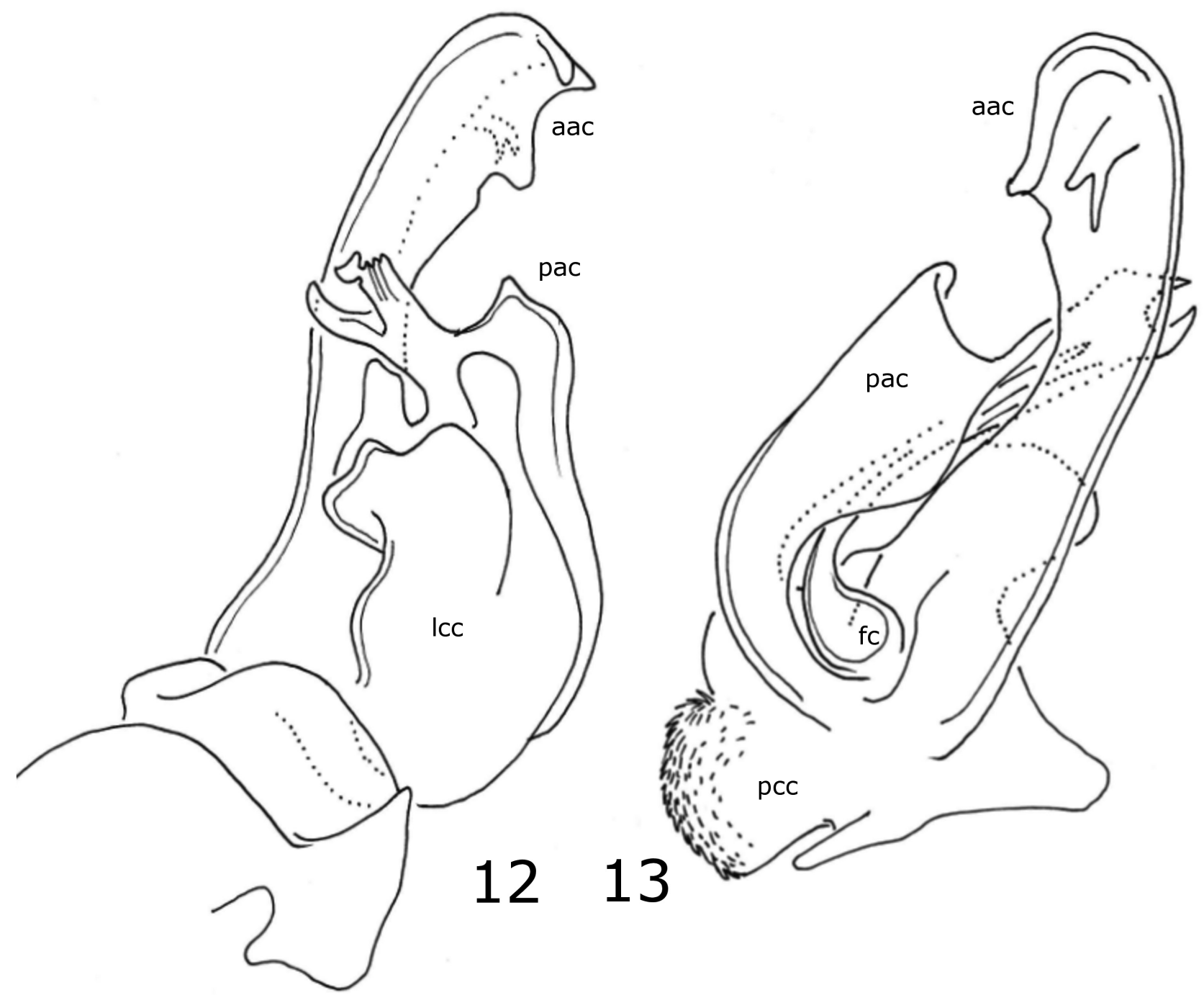

FIGURES 12, 13. Amplaria oedipus, n. sp., male holotype. Fig. 12. Right gonopod, lateral view; aac, anterior angiocoxite; pac, posterior angiocoxite; lcc, lateral lobe of colpocoxite. Fig. 13. Right gonopod, mesal view; aac, anterior angiocoxite; fc, flagellocoxite; pcc, posterior lobe of colpocoxite; pac, posterior angiocoxite. Without scale.

When the first male was collected by PN and sent to WS for identification we suspected the strange tarsi might have been due to a parasite, such as a nematode or a fly larva. However, dissection of one of the tarsi revealed neither, just amorphous tissue. Also, why would a parasitic attack be limited to just those tarsi? Another consideration was that a random mutation may have occurred in the single male. The collection by PN of another male with the exact same greatly inflated tarsi on the 5th and 6th legpairs spoke against both the parasite and mutation hypotheses. We therefore think that the evidence at hand supports our conclusion that the modifications are normal for the mature males of this species. In our experience, such a tarsal condition is not known from any other species of the class Diplopoda, though enlarged other podomeres (usually the prefemora) are not unusual. Aside from the enlarged tarsi, A. oedipus is a typical species of Amplaria.

The unique nature of this modification recalls the eastern North American species Pseudotremia peponocranium Shear, 2011 (Cleidogonidae) which differs from all other members of its genus in having a large, swollen, quadrate projection on the front of the head in both males and females (Shear 2011: 15, figs 34, 35).

A single male and two female Amplaria of another, undescribed species were collected at a lower elevation on Cape Mountain $\left(44.0910^{\circ} \mathrm{N},-124.0737^{\circ} \mathrm{W}\right)$. The gonopods of this species, to be described later, are similar but distinct from those of $A$. oedipus and the male lacks the enlarged tarsi. 


\section{Key to species of Amplaria}

Key based on males. Amplaria eutypa and A. eldora are not included (both descriptions based on females only).

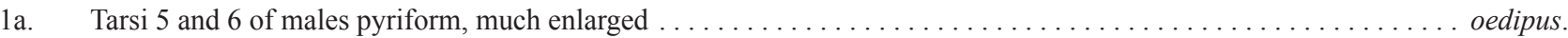

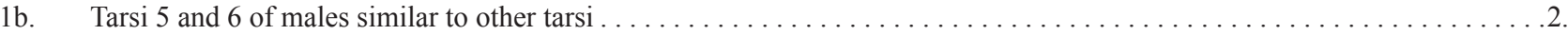

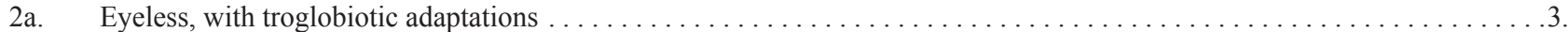

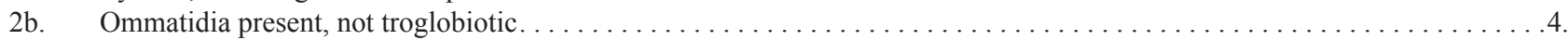

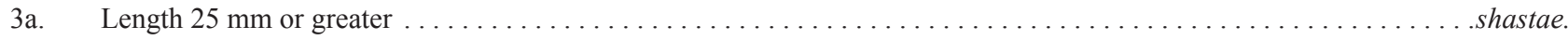

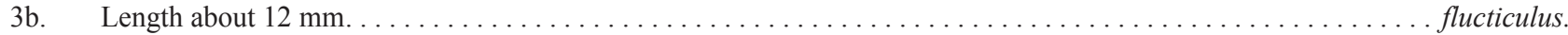

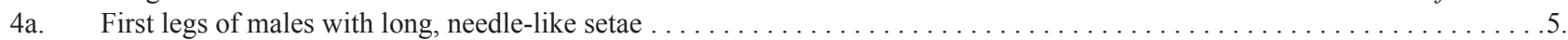

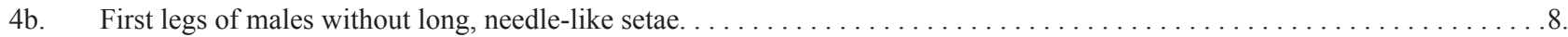

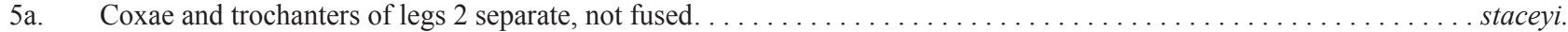

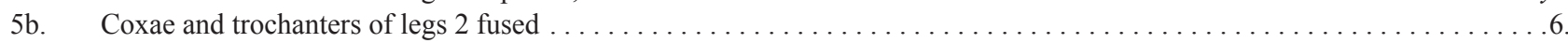

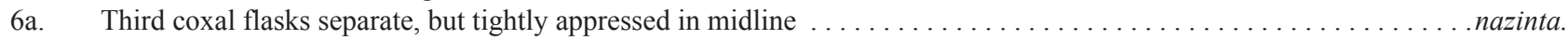

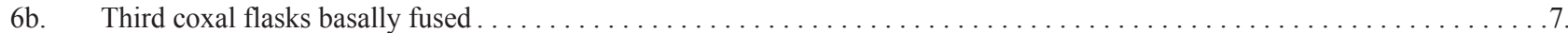

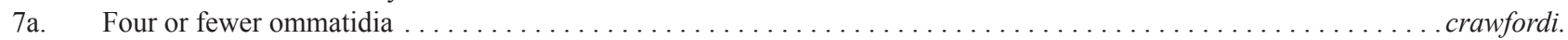

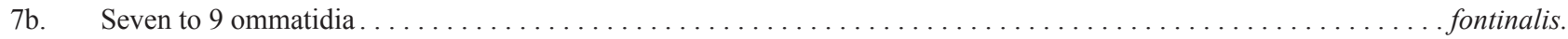

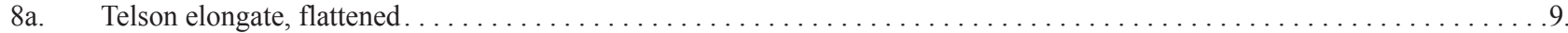

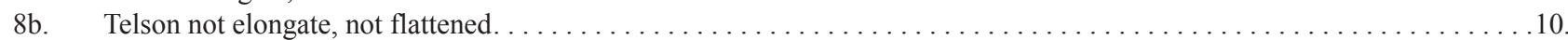

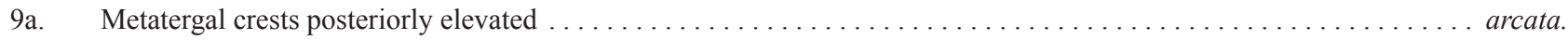

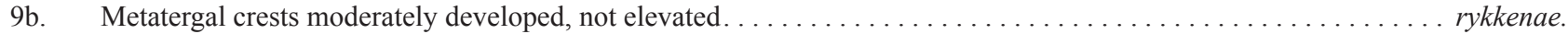

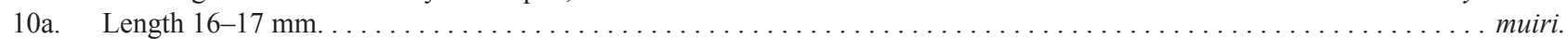

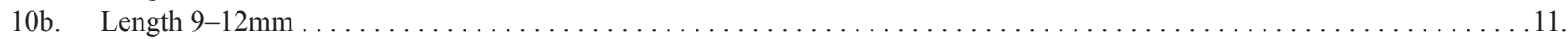

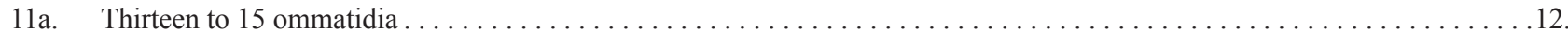

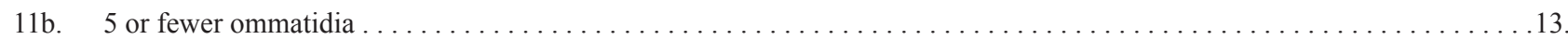

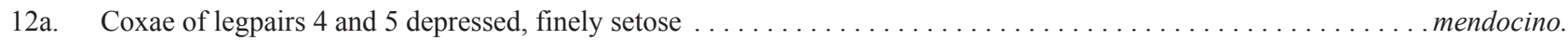

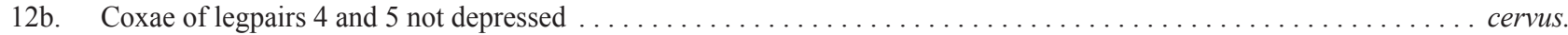

13a. Process of second trochanter very short or apparently absent $\ldots \ldots \ldots \ldots \ldots \ldots \ldots \ldots \ldots \ldots \ldots \ldots \ldots \ldots \ldots \ldots$.

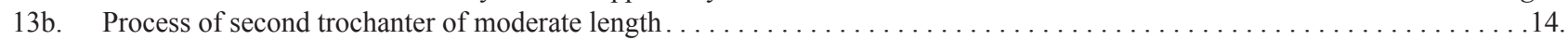

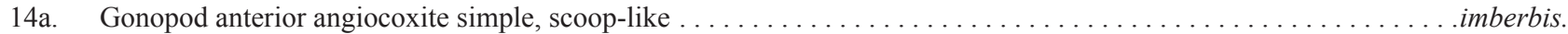

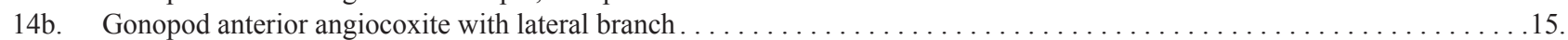

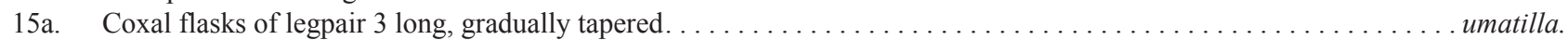

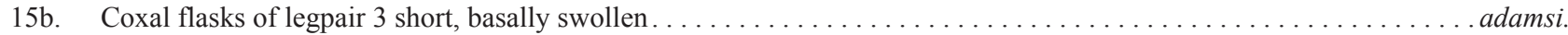

\section{List of species}

Species

adamsii Shear \& Krejca, 2007

arcata Shear, 2021a

baughi Shear, 2021a

cervus Shear, 2021a

crawfordi Shear, 2021a

eldora (Chamberlin, 1953)

eutypa (Chamberlin, 1941)

flucticulus Shear, 2021a

fontinalis Shear, 2021a

imberbis (Loomis, 1936)

mendocino Shear, 2021a

muiri Shear \& Krejca, 2007

nazinta (Chamberlin, 1910)

oedipus n. sp.

rykkenae Shear, 2021a

shastae (Causey, 1958)

staceyi Shear, 2021a

umatilla Shear, 2021a
Type Locality

CALIFORNIA: Tulare Co., Hidden Cave, Sequoia National Park

CALIFORNIA: Humboldt Co., Prairie Creek Redwoods State Park, 41.3730, $-124.0139^{\circ}$

IDAHO: Idaho Co., O’Hara Campground, $46.0852^{\circ},-115.5174^{\circ}$

CALIFORNIA: Humboldt Co., 6 mi N of Loleta, 40.6991ํ $-124.1168^{\circ}$

WASHINGTON: King Co., Thornton Creek, $47.698^{\circ},-122.279^{\circ}$

CALIFORNIA: Eldorado Co., Crystal Cosumnes Cave

CALIFORNIA: Eldorado Co., 9 miles N of Placerville

CALIFORNIA: Amador Co., Rippled Cave, $38.4386^{\circ},-120.7255^{\circ}$

WASHINGTON: Skamania Co., Spring Creek Hatchery, $45.7280^{\circ},-121.5445^{\circ}$

CALIFORNIA: San Luis Obispo Co., south of Atascodero

CALIFORNIA: Mendocino Co., Usal Road, 39.7910. $-123.8290^{\circ}$

CALIFORNIA: Tulare Co., Crystal Cave, Sequoia National Park

OREGON: Multnomah Co., Powell Butte Park, $45.4888^{\circ},-122.5131^{\circ}$ (neotype)

OREGON: Lane Co., Cape Mountain, $44.0947^{\circ},-124.0756^{\circ}$

OREGON: Linn Co., Willamette National Forest, $44.4131^{\circ},-122.2619^{\circ}$

CALIFORNIA: Shasta Co., Samwel Cave

CALIFORNIA: San Diego Co., Palomar Mountain State Park, 33.3435º, $-116.9072^{\circ}$

OREGON: Umatilla Co., Umatilla National Forest, $49.9801^{\circ},-118.0523^{\circ}$ 


\section{Acknowledgements}

We thank Virginia Tech's NFCL (ICTAS) for access to scanning electron microscopy, facilitated by a grant from the National Science Foundation of the United States (\#1916368) to Paul Marek at Virginia Tech and Michael Caterino at Clemson University. Thanks are due to Dragan Antic and Sergei Golovatch for their reviews, which improved the paper.

\section{References}

Bollman, C.H. (1888) Notes upon a collection of Myriapoda from East Tennessee, with a description of a new genus and six new species. Annals of the New York Academy of Sciences, 4 (106), 1-12.

Bollman, C.H. (1893) The Myriapoda of the United States. United States National Museum Bulletin, 43, 1-210.

Bond, J.E., Godwin, R.L., Colby, J.D., Newton, L.G., Zahnle, X.J., Agnarsson, I., Hamilton, C.A. \& Kuntner, M. (2021) Improving taxonomic practices and enhancing its extensibility-an example from Araneology. Diversity, 14, 1-15. http://doi.org/10.3390/d14010005

Chamberlin, R.V. (1941) New Western millipeds. Bulletin of the University of Utah, Biological Series, 31 (2), 6, 3-23.

Hennig, E. (1915) Kentrosaurus aethiopicus, der Stegosauridae das Tendaguru. Sitzungberichte der Gesellschaft Naturforschender Freunde zu Berlin, 1915, 219-247.

Kemperman, T. \& Gittenberger, E. (1988) On morphology, function and taxonomic importance of the shell ribs in Clausiliidae (Mollusca: Gastropoda: Pulmonata) with special reference to those in Albinaria. Basteria, 52, 77-100. [https://natuurtijdschriften.nl/pub/596881]

Marsh, O.C. (1877) A new order of extinct Reptilia (Stegosauria) from the Jurassic of the Rocky Mountains. American Journal of Science, 3, 513-514.

Shear, W.A. (1973) Millipeds from Mexican and Guatamalan caves. Accademia Nazionale dei Lincei, Problemi attuali di scienza e di cultura, 171, 239-305.

Shear, W.A. (2011) Cave millipedesof the United States. X. New species and records of the genus Pseudotremia Cope. 2. Species from Virginia, USA (Diplopoda, Chordeumatida, Cleidogonidae). Zootaxa, 3109, 1-38.

Shear, W.A. (2020) The millipede family Striariidae Bollman, 1893. I. Introduction to the family, synonymy of Vaferaria Causey with Amplaria Chamberlin, the new subfamily Trisariinae, the new genus Trisaria, and three new species (Diplopoda, Chordeumatida, Striarioidea). Zootaxa, 4758 (2), 275-295. https://doi.org/10.11646/zootaxa.3109.1.1

Shear, W.A. (2021a) The millipede family Striariidae Bollman, 1893. II. New records and species of the genus Amplaria Chamberlin, 1941 (Diplopoda, Chordeumatida, Striarioidea). Zootaxa, 4908 (2), 205-224. https://doi.org/10.11646/zootaxa.4908.2.3

Shear, W.A. (2021b) The millipede family Striariidae Bollman, 1893. III. Four new species of Striaria Bollman, 1888 (Diplopoda, Chordeumatida, Striarioidea). Zootaxa, 4920 (3), 395-406. https://doi.org/10.11646/zootaxa.4920.3.5

Shear, W.A. \& Krejca, J.K. (2007) Revalidation of the genus Amplaria Chamberlin 1941 (Diplopoda, Chordeumatida, Striariidae) and description of two new species from caves in Sequoia and Kings Canyon National Parks, California. Zootaxa, 1532 (1), 23-39. https://doi.org/10.11646/zootaxa.1532.1.2

Shear, W.A., Nosler, P. \& Marek, P.E. (2017) The identity of Amplaria nazinta (Chamberlin, 1910): a century-old millipede mystery resolved (Diplopoda, Chordeumatida, Striariidae). Zootaxa, 4311(2), 233-240.

https://doi.org/10.11646/zootaxa.4311.2.4 